Bolm. Zool., Univ. S. Poulo $4: 39-52,1979$

\title{
SOME ENCHYTRAEIDAE (OLIGOCHAETA) FROM SERRA DO MAR, SÃO P’AULO, BRAZIL
}

\author{
Martin Lindsey Christoffersen \\ Departamento de Zoologia, \\ Instituto de Biociências, \\ Universidade de São Paulo \\ Caixa Postal 20.520 - Sāo Paulo - Brasil
}

\section{RESUMO}

Os animais foram coletados num pequeno trecho da nossa floresta tropical latifoliada úmida de encosta. Hemienchytraeus (H.) stephensoni (Cognetti, 1927) foi encontrado pela primeira vez no Brasil, sendo redescrito. Discutem-se ainda pequenas diferenças morfológicas de Fridericia bulbosa (Rosa, 1887), $F$. agricola Moore, 1895 e $F$. bollonsi Benham, 1914, com relação a descrições anteriores do Estado de Sð̃o Paulo.

\begin{abstract}
Specimens were collected from a small portion of the tropical rain forest region of Brazil's east coast. Hemienchytraeus (H.) stephensoni (Cognetti, 1927) has been found for the first time in Brazil and is redescribed. Fridericia bulbosa (Rosa, 1887), F. agricola Moore, 1895 and $F$ bollongsi Benham, 1914 are discussed regarding slight morphological differences in relation to previous descriptions from the State of São Paulo.
\end{abstract}

\section{INTRODUCTION}

Earth samples containing enchytraeid worms were collected at Engenheiro Marsilac (23054'S 46043'W), Evangelista de Souza (23056'S 46039' W) and Engenheiro Ferraz (23059'S 46037' W), situated at the boundaries of the municipalities of São Paulo and São Vicente, State of São Paulo, Brazil. The climatic conditions of this rain forest region are summarized in a previous paper (Christoffersen, 1977: 187). 


\section{METHODS}

The worms were studied alive, fixed in Bouin and preserved in alcohol $70 \%$ Some specimens were stained with Mayer's Paracarmin and mounted on slides, while others were further microtomized into $7 \mu \mathrm{m}$ cross sections and stained with Ehrlich's Haematoxylin and Eosin.

The length and width of the animals refer to preserved specimes. Further measurements and drawings, except when otherwise mentioned, were made from living and sexually mature worms.

The material is deposited in the Departament of Zoology, University of São Paulo (ZU).

\section{RESULTS}

\section{Hemienchytraeus (H.) stephensoni (Cognetti, 1927)}

Figs. 1-23

Enchytraeus cavicola (non Joseph, 1880) Stephenson, 1924: 127, pl. 6 figs. 14; E. stephensoni Cognetti de Martiis, 1927: 4 (nom. nov.); E. myrmecophilus Cernosvitov, 1930: 85, figs. 1-9; E. rangoonensis Stephenson, 1931:177, fig. 1; Hemienchytraeus stephensoni Cernosvitov, 1934: 298, figs. $1-11$; 1937: 153; 1939: 92, figs. 43-49; $H$. (H.) stephensoni; Righi, 1974: 130.

Material - Evangelista de Souza, close to Ribeirão dos Monos, 7 animals of variety A(ZU-31A, in alcohol), 7 animals of variety B (ZU-351B, 1 in alcohol, 2 in cross sections), 13 animals of variety C (ZU-351C, in alcohol), 26 animals of variety D (ZU-351D, 20 in alcohol, 3 as whole mounts, 3 in cross sections), M.L. Christoffersen col. from 20.1.1975 to 7.12.1975; Engenheiro Marsilac, under plant debris in forest soil, 2 animals of variety A (ZU-364A, in alcohol), and 3 animals of variety C (ZU-364C, in alcohol), M.L. Christoffersen col. 1.8.1975.

Description - The size of varieties A to D ranges as follows:

A

body length $(\mathrm{mm})$

width of clitellum (mm)

width at middle of body $(\mathrm{mm})$

number of body segments $(\mathrm{mm})$
$6,5-8$

$0,26-0,36$

$0,24-0,31$

$30-42$
B

8-9

$0,25-0,28$

$0,22-0,25$

3742
C

7,5-10

$0,18-0,27$

$0,15-0,26$

3148
D

7-10

0,19-0,31

$0,16-0,23$

$33-47$

There are two setae per lateral and ventral bundle. The first body segments have thick, slightly curved setae, measuring $3248 \mu \mathrm{m}$ in length (Fig. 1). Backwards the setae become thinner and straighter, being of the same length or shorter than the anterior ones; 


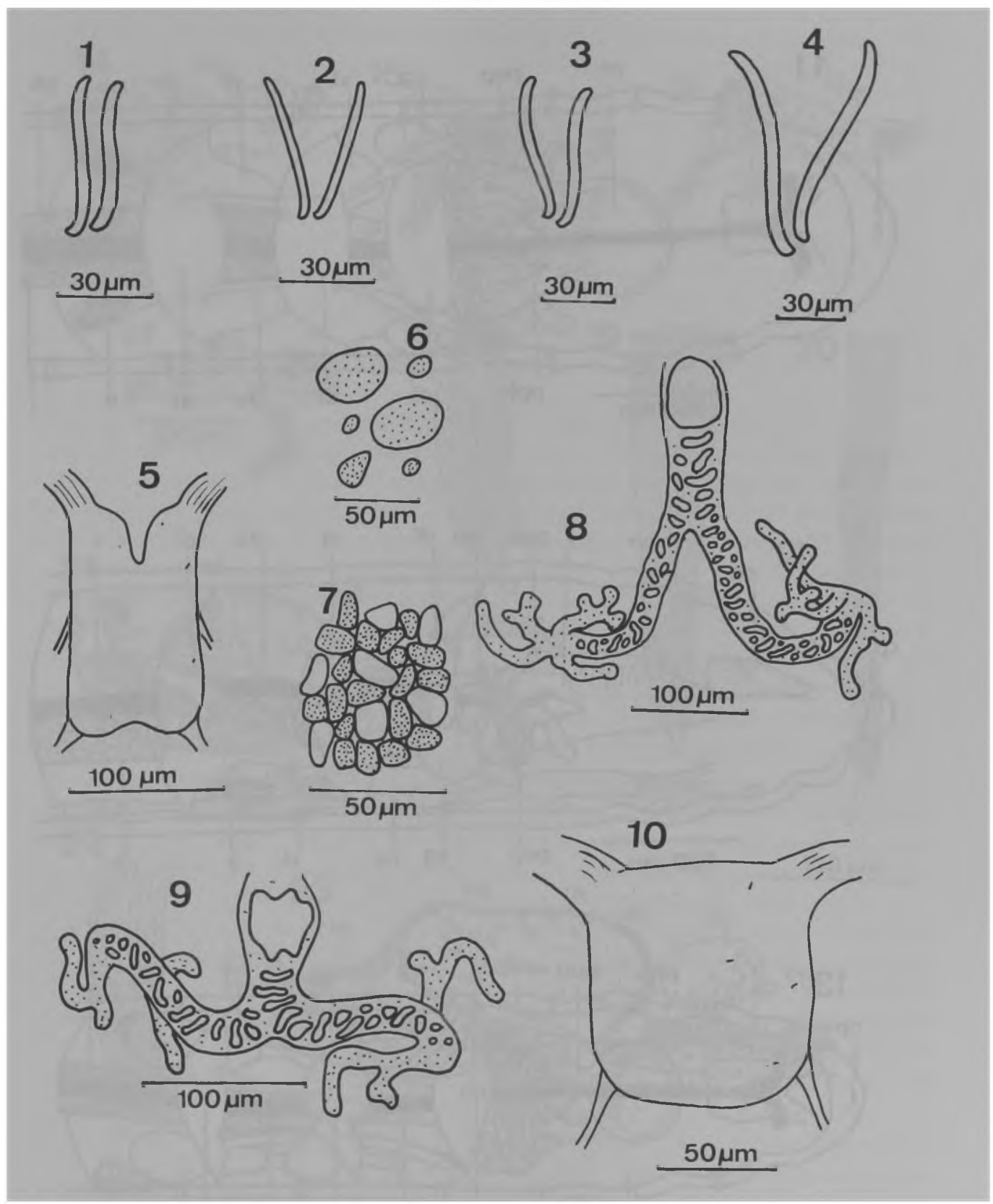

Fig. 1 a $10-1$ Lateral setae of segment II, variety $D$. 2 - Ventral setae of segment XVI, variety B. 3 - Ventral setae of posterior body segment, variety $D$. 4 - Ventral setae of posterior body segment, variety $A$. 5 - Cerebral ganglion in dorsal view, variety $B$. 6 - Coelomic corpuscles, variety $B$. 7 - Dorsal view of clitellar cells, from preserved specimen. $8-$ Peptonephridium in dorsal view, variety $A$. 9 - Peptonephridium in dorsal view, variety $B .10-$ Cerebral ganglion in dorsal view, variety $\boldsymbol{A}$. 

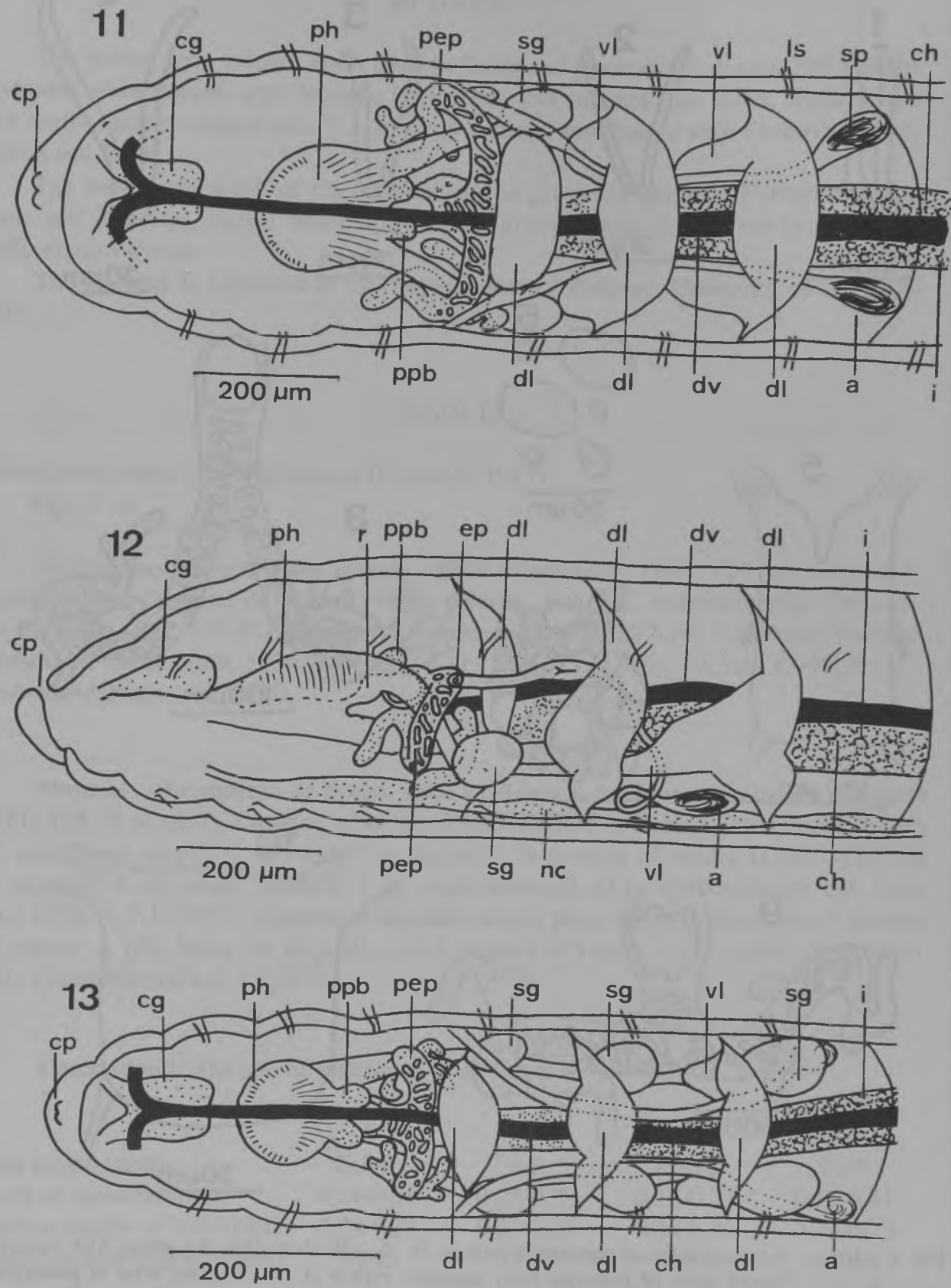

Fig. 11 a $13^{\circ}-11$ - Anterior body region in dorsal view, variety $A .12$ - Anterior body region in lateral view, variety $B .13$ - Anterior body region in dorsal view, variety $D$. 


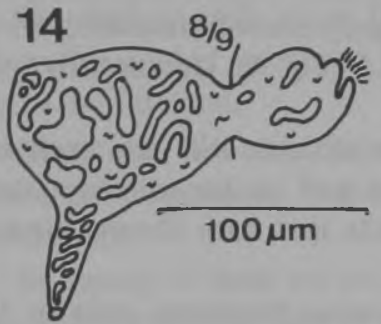

15

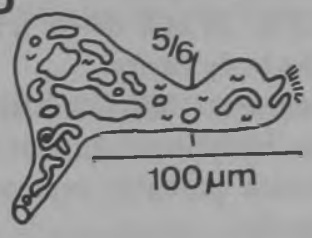

18

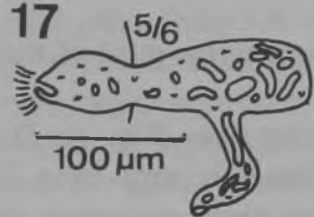

21

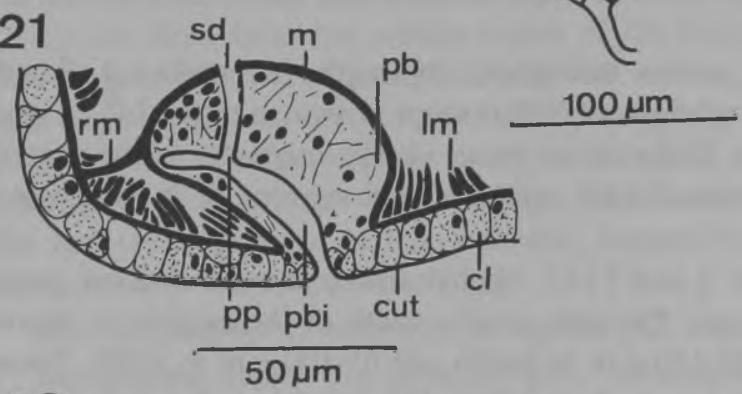

22
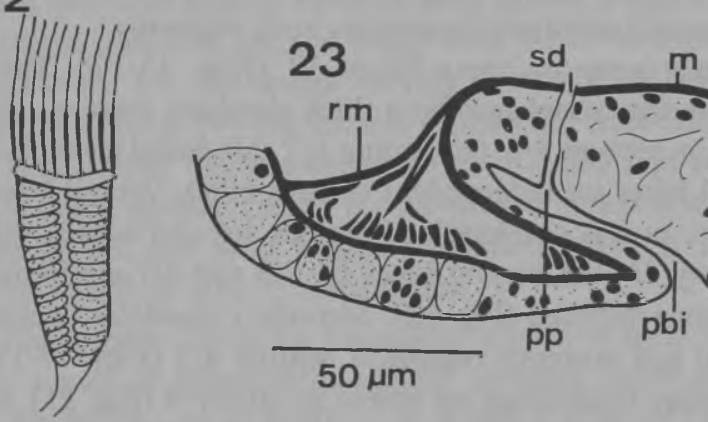

$50 \mu \mathrm{m}$

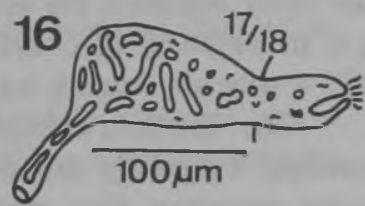

19

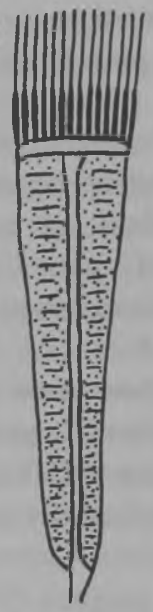

$100 \mu \mathrm{m}$

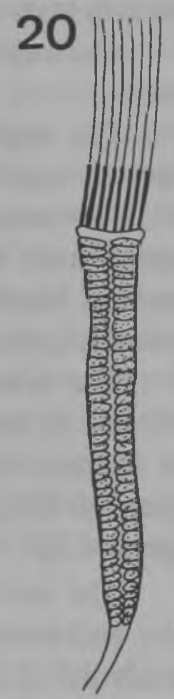

$100 \mu \mathrm{m}$

$100 \mu \mathrm{m}$

Fig. 14 a 23 - 14 - Nephridium of septum 8/9, variety $B$. 15 - Nephridium of septum 5/5, variety $B$. 16 - Nephridium of septum $17 / 18$, variety $D .17$ - Nephridium of septum $5 / 6$, variety $D .18$ - Seminal funnel, variety $A .19$ - Seminal funnel, variety $C$. 20 - Seminal funnel, variety $B$. 21 - Penial bulb in cross section, variety $B .22$ - Seminal funnel, variety D. 23 - Penial bulb in cross section, variety $D$. 
their length in the middle region of the body varies from 32 to $40 \mu \mathrm{m}$ (Fig. 2). In the last body segments the setae become again thick and slightly curved, measuring 44-61 $\mu \mathrm{m}$ in length in $B, C$ and $D$ (Fig. 3) and 69-89 $\mathrm{m} \mathrm{m}$ in $A$ (Fig. 4). Occasionally tufts of $2-4$ setae are found lying in the body cavity.

The clitellum occupies segments XII-1/3 XIII. The clitellar cells are small and arranged irregularly around the body wall. In the dorsal half of the clitellum there occur numerous clear spaces which probably represent cells that have already discharged their granular secretions (Fig. 7).

Well developed cutaneous gland cells form conspicuous transverse rows in the dorsal region of the anterior body segments, especially on the prostomium and the first two body segments. mium.

The cephalic pore (Figs. 11-13, cp) is placed on the anterior third of the prosto-

The majority of the coelomic corpuscles occur in two sizes (Fig. 6). The bigger ones are approximately elliptical and their maximum diameters vary from 28 to 37 $\mu \mathrm{m}$. The smaller ones are rounded or of irregular shape, their maximum diameters varying from 9 to $12 \mathrm{~m}$. Coelomic corpuscles of intermediate sizes occur in smaller numbers. Each coelomic corpuscle has a central nucleus and is finely and not very conspicuously granulated.

The dorsal blood vessel is narrow throughout its length. In varieties $A, B$ and $C$ it begins in the posterior region of segment XIII, except in two animals of $C$, in which the origin is in segment XIV. In $D$ the dorsal vessel usually originates in the posterior region of $\mathrm{XV}$, exceptionally in the anterior region of this segment or in the posterior region of XIV

The cerebral ganglion (Figs. 5 and 11-13, cg) has a deep anterior incision, parallel sides and a convex posterior margin. The ratio length: width of the ganglion is approximately 1,5:1 and it measures 100-150 $\mu \mathrm{m}$ in length and 65-100 $\mu \mathrm{m}$ in width. Sometimes the cerebral ganglion appears squase-shaped (Fig. 10), but this is due to the posture of the worm, occuring when the animal contracts its anterior body segments.

Three pairs of septal glands occur on septa IV to VI (Figs. 11-13). The dorsal lobes (dl) are connected above the oesophagus by a thick glandular mass on septum $4 / 5$ and a relatively thinner mass on septum $5 / 6$. On septum $6 / 7$ this dorsal glandular connection is very thin or the dorsal lobes are independent of each other. Ventral lobes (vl) are absent from septum $4 / 5$, more or less developed on septum $5 / 6$ and usually well developed on septum $6 / 7$. In variety $D$ the ventral lobes of $5 / 6$ and $6 / 7$ are frequently less developed than in the remaining varieties (Fig. 13). Secondary glandular thickenings are always present in the ventral and posterior regions of septum 4/5 (Figs. 11-13, sg). In septa $5 / 6$ and 6/7 these secondary thickenings are absent in variety $A$ (Fig. 11), absent or slightly developed in $B$ and $C$ (Fig. 12) and well developed in $D$ (Fig. 13).

A dorsal peptonephridium (Figs. 8-9 and 11-13, pep) leads into a small recess (Fig. $12, \mathrm{r}$ ) in the posterior region of the pharynx (Figs. 11-13, ph). In its distal portion the organ bifurcates into primary branches that lead downwards at each side of the oesophagus. Ventrally each primary branch is further divided into a variable number of secondary branches of smaller diameter and irregular shape. The peptonephridial lumen is only visible in the dorsal and primary branches, consisting of twisting channels that, before leading into the pharynx, widen into a voluminous chamber of variable shape and size. 
There is no clear-cut transition from oesophagus to intestine.

Chloragogen cells occur from segment V backward, more densely from VI. They are conspicuous but usually it is possible to discern their cellular contours only posteriorly to the clitellum.

Sometimes intestinal cells containing bigger and more brightly coloured yellow granules are conspicuous begining between segments XIII and XIV and ending between $\mathrm{XX}$ and XXIV.

In variety $A$ there are six pairs of pre-clitellar nephridia on septa $5 / 6$ to $10 / 11$. In $B$ and $D$ there are five pairs of pre-clitellar nephridia (Figs. 14,15 and 17) on septa $5 / 6$ to $9 / 10$, except in one animal of $D$, where a sixth pair is present on septum $10 / 11$. In $C$ there are four pairs, from $5 / 6$ to $8 / 9$, except in one animal, where the first pair is absent. Posteriorly to the clitellum the nephridia occur from 13/14 backward in $B, C$ and $D$ (Fig. 16) and begin anywhere between septa $14 / 15$ and $16 / 17$ in $A$. The post-clitellar nephridia occur on successive septa, but frequent interruptions occur in their arrangement, which is variable from one animal to another. The nephridia of the first pair (Figs. 15 and 17) measure 90-120 $\mu \mathrm{m}$ in length, those near the clitellum measure 110$160 \mu \mathrm{m}$, those of the middle region of the body $160-215 \mu \mathrm{m}$ and those of the last segments $60-100 \mu \mathrm{m}$. In the first pairs of nephridia the ratio post-septal: preseptal portion is 1,5-2:1, in those from the middle region of the body 2-2,5:1 and in those from the posterior segments 1:1. The nephridial ducts are narrow, never exceeding half the length of each nephridium. In variety $A$ the ducts arise midway along the ventral margins of the post-septal portions of the nephridia, only occasionally originating nearer the septum in pre-clitellar nephridia. In $B, C$ and $D$ (Figs. 14-17) the ducts arise in the posterior half of the post-septal portions of the nephridia, frequently having terminal or subterminal positions in the post-clitellar nephridia.

Few maturing sperm cells occur in segment $\mathrm{XI}$, seminal.vesicles being absent.

The seminal funnels are approximately cylindrical in varieties $A$ and $B$, but in $A$ (Fig. 18) the ratio length: width of each funnel is approximately 3:1, the length varying from 100 to $120 \mu \mathrm{m}$ and the width from 30 to $40 \mu \mathrm{m}$, while in $B$ (Fig. 20) this ratio is approximately $5: 1$, the length varying from 170 to $215 \mu \mathrm{m}$ and the width from 30 to $45 \mu \mathrm{m}$. In $C$ (Fig. 19) the seminal funnels are cone-shaped, the ratio length: maximum width is 3-5:1 and the measurements are 100-305 $\mu \mathrm{m}$ and 30-60 $\mu \mathrm{m}$, respectively. In $D$ (Fig. 22) each seminal funnel is cone-shaped or has lateral margins only slightly converging backward, the ratio length: maximum width is 2-3:1 and the measurements are 70-165 $\mu \mathrm{m}$ and 35-60 $\mathrm{m}$, respectively.

The seminal ducts are irregularly wound or form tight coils in segment XII. They lead to a pair of spherical or slightly elongate penial bulbs, measuring $65-100 \mu \mathrm{m}$ in length by $65-70 \mu \mathrm{m}$ in width in $A, B$ and $C$ (Fig. 21) and $85-165 \mu \mathrm{m}$ by $55-100 \mu \mathrm{m}$, respectively, in $D$ (Fig. 23). The bulbs sometimes appear bilobed in living animals. Each penial bulb consists of a glandular mass of cells of a single type (Figs. 21 and 23, pb), enveloped by a thin muscular coating $(\mathrm{m})$. Each seminal duct (sd) leads into the penial lumen (pbi) by the penial pore (pp), before the body surface is reached.

A posterior ovisac extends backward to septum $16 / 17$, contains one to three developed egg cells, which occupy the length of 1-1,5 successive segments each, as well as several smaller developing eggs. 
The spermathecal pores are situated laterally in the anterior region of segment $\mathrm{V}$, just below the lines formed by the lateral setal follicles, associated glands being absent. In the middle of segment $\mathrm{V}$ each spermathecal duct widens into a small chamber which sometimes contains a small number of sperm cells. When the spermathecae are completely extended backward, the ampullae lie free in segment VII (Figs. 11-13, a), sometimes in VIII and more rarely in IX in varieties $C$ and $D$. The ampullae are narrow and long in $A, B$ and $C$ (Figs. 11 and $12, \mathrm{a}$ ), measuring $100-115 \mu \mathrm{m}$ in length and $30-45 \mu \mathrm{m}$ in width in $A$ and $B$ and $120-205$ by $25-40 \mu \mathrm{m}$ in $C$. In $D$ the ampullae are spherical or slightly ellyptical (Fig. 13, a), measuring $40-50 \mu \mathrm{m}$ in length by $25-40 \mu \mathrm{m}$ in diameter.

Discussion - Cernosvitov (1934) examined the type material of the Asian species Enchytraeus cavicola Stephenson, 1924 and E. rangoonensis Stephenson, 1931 and of the South American species $E$. myrmecophilus Cernosvitov, 1930. He was unable to find morphological characters that could be used to distinguish these species, and thus grouped them all under the name Henienchytraeus stephensoni (Cognetti, 1927).

Later on, Cernosvitov (1939) pointed out that this species showed great intraspecific variability thoughout its South American range. Further variants of what seems to be a highly polymorphic species are described herein, but there is a possibility that $H$. $(H$.) stephensoni, as presently defined, may constitute a complex group of cryptic species.

Geographical distribution - India: Assam (Stephenson, 1924: 127), Burma: Rangoon (Stephenson, 1931:177); Bolivia: near Titicaca lake (Cernosvitov, 1939: 92); Paraguay: banks of Parana river (Cernosvitov, 1934: 298); Argentine: Province of Misiones (Cernosvitov, 1930: 85; 1937: 153); Brazil: São Paulo (new locality).

\section{Fridericia bulbosa (Rosa, 1887)}

Neoenchytraeus bulbosus Rosa, 1887: 2; Fridericia bulbosa; Nurminen, 1966: 68, 1967a: 149; 1967b: 586; 1970: 204; 1973a: 400; 1973b: 413; 1973c: 478; Bittencourt, 1974: 371, figs. 11-16; Christoffersen, 1976: 240, figs. 1-15 (with further references).

Material - Engenheiro Marsilac, in damp earth slope, 9 animals of variety $B$ (ZU-360, in alcohol), M.L. Christoffersen col. 1.7.1975; Engenheiro Ferraz, near railroad tracks, 7 animals of variety $B$ (ZU-366B, in alcohol) and 20 animals of variety $C(Z U-366 C$, alcohol), M.L. Christoffersen col. 21.12.1975.

Discussion - A list of the geographical distribution and references for this species have been given in a previous paper (Christoffersen,1976:240). Of the three varieties then recognized, the present material could be identified with those refered to as $B$ and $C$. The following remarks may be added to or differ from the previous description:

The number of segments is 40-55 in $B$ and 39-63 in $C$. The dorsal blood vessel arises between segments XVII and XX in $B$ and between XVI and XX in $C$. Each peptonephridium of $C$ may be undivided or have up to five terminal branches, some of which may bifurcate at the tip. Chloragogen cells in $B$ and $C$ occur from segment $\mathrm{V}$ 
backward, having distinct cellular contours. There are five pairs of pre-clitellar nephridia, on septa $6 / 7$ to $10 / 11$. Well developed seminal vesicles are absent. The penial bulbs attain $120 \mu \mathrm{m}$ in length in $B$ and $160 \mu \mathrm{m}$ in $C$.

\section{Fridericia agricola Moore, 1895}

(Figs. 24-30)

Fridericia agricola Moore, 1895: 342, pl. 13 figs. 1-3, 7; Michaelsen, 1900: 97; Friend, 1912: 14; Welch, 1914: 153 (key); Bell, 1936: 155 (key); Backlund, 1947: 13, figs. 7-9; Christoffersen, 1973: 340; Bittencourt, 1974: 374, figs. 17-24.

Material - Engenheiro Ferraz, Km 74 of São Paulo-Santos railroad, 6 animals (ZU365), M.L. Christoffersen col. 21.12.1975.

Discussion - The species is well characterized by the descriptions in Moore (1895), Michaelsen (1900), Backlund (1947), Christoffersen (1973) and Bittencourt (1974). Only some morphological aspects are discussed below and they are compared with the previous accounts only when they are found to differ from them.

The worms measure $21-25 \mathrm{~mm}$ in length $(9-11 \mathrm{~mm}$ in Backlund's material). The width in the clitellar region is $0,49-0,58 \mathrm{~mm}$ and in the middle region of the body 0,43 $0,51 \mathrm{~mm}$ (Bittencourt indicates $0,34 \mathrm{~mm}$ in both these regions). The number of segments is 65-74.

The setae agree with Bittencourt's account (1974: 374), but occasionally some tufts with six setae each occur in pre-clitellar segments.

The clitellum occupies segments XII-1/2 XIII (3/4 XI-XIII in Backlund's material). The clitellar cells have irregular contours and an average diạmeter of $12 \mu \mathrm{m}$, being arranged irregularly around the body wall (Backlund and Bittencourt indicate an arrangement in regular transverse rows).

The feminine pores are represented by a pair of conspicuous transverse slits in the anterior region of segment XIII, in line with the ventral tufts of setae.

Conspicuous cutaneous gland cells are absent or little developed, sometimes forming 1-3 incomplete transverse rows, in line with the setal follicles of each segment. More conspicuous cutaneous glandular cells occur irregularly around the ectal pores of the spermathecae (Fig. 28, cc).

The coelomic corpuscles are elliptical and clear, occuring in two sizes. The bigger ones have a central nucleus and measure 53-61 $\mu \mathrm{m}$ in their maximum diameters. The smaller ones are anucleate, measuring $8-10 \mu \mathrm{m}$ in their maximum diameters.

The dorsal blood vessel begins between septa 22/23 and 25/26 (20/21 in Backlund's material).

The cerebral ganglion (Fig. 26) is rounded in front and behind, measuring on an average $200 \mu \mathrm{m}$ in length and $100 \mu \mathrm{m}$ in maximum width (Bittencourt indicates 140 by $95 \mu \mathrm{m}$, respectively, in preserved specimens).

The peptonephridia ramify distally into $5-8$ tubular branches which are simple or bifurcate, agreeing closely with Moore's drawing (1895, PI. XIII, fig. 7). 


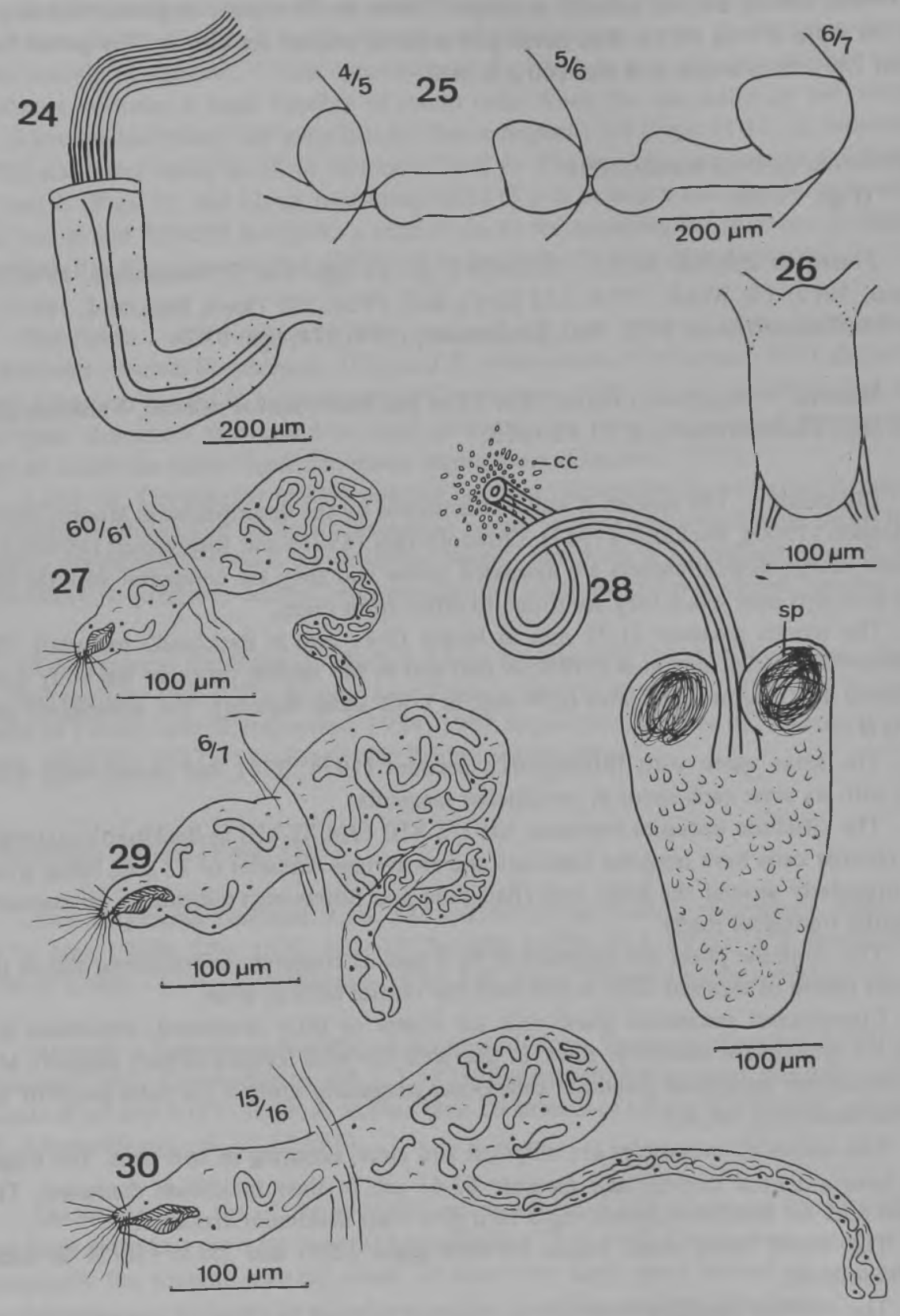

Fig. 24 a 30 - 24 - Seminal funnel. 25 - Lateral view of septal glands. 26 - Cerebral ganglion, dorsal view. 27 - Nephridium of septum 60/61. 28 - Spermatheca. 29 - Nephridium of septum 6/7. $30-$ Nephridium of septum 15/16. 
The septal glands of septa 5/6 are often mutually independent, as those of $6 / 7$, and ventral lobes are absent from septum $4 / 5$ (Fig. 25). The dorsal lobes of the second pair of septal glands are very thin and transparent, due to que great volume of the spermathecal ampullae in segment $\mathbf{V}$

The chloragogen cells have distinct contours and are well developed from segment VI backward, so as to obscure the intestinal lumen in living animals.

The nephridia (Figs. 27, 29 and 30) are described in detail by Backlund (1947:16), Christoffersen (1973:340) and Bittencourt (1974: 375), but differences occur between the Swedish worms and those from Sao Paulo, especially with regard to the first pair on septum 6/7. These, in Backlund's material, are not very bulky, are not constricted at the insertion of the septum and have a terminal excretory duct.

There is an anterior seminal vesicle occupying segment $X$ and a posterior pair occupying segment XII and frequently also segment XIII.

The seminal funnels are cylindrical (Fig. 24), measuring 640-800 $\mu \mathrm{m}$ in length by $160-195 \mu \mathrm{m}$ in width (Backlund indicates 215 by $105 \mu \mathrm{m}$ and Bittencourt 360 by 80 $\mu \mathrm{m}$, in preserved specimens). Due to their great dimensions, the funnels are almost always bent back over themselves. The collar of each funnel is just as broad as the organ and to it is attached a narrow and long tuft of reddish-brown sperm cells.

The seminal ducts are long and irregularly wound, filling segment XIII with many loops. Each seminal duct leads into a voluminous penial bulb, measuring 320-345 $\mu \mathrm{m}$ in length and 110-140 $\mu \mathrm{m}$ in width.

One or two well developed eggs, occupying the length of one segment each, lie between segments XII and XIV

The spermathecal ampullae are conical and very bulky (Fig. 28), connecting with the digestive tube laterally in the posterior region of segment $\mathrm{V}$ Each ampulla measures on an average $360 \mu \mathrm{m}$ in length, including the diverticles at the proximal end, and $160 \mu \mathrm{m}$ in its broadest width. The ectal duct of each spermatheca is thick, forming a loop in segment $\mathrm{V}$. being 1-1,5 times longer than the ampulla (Moore indicates each duct as being 6-7 times longer than the ampulla).

The material collected in the State of São Paulo (Christoffersen, 1973, Bittencourt, 1974 and the worms treated here) agrees reasonably well with Moore's description of Fridericia agricola from Philadelphia. On the other hand, the systematic position of the Swedish specimens (Backlund, 1947) is not so certain because several characteristics resemble those of Fridericia perrieri (Vejdovsky, 1877) "sensu" Michaelsen (1900: 98), having been included in this species by Nielsen \& Christensen (1959: 82). The diagnosis of $F$. perrieri given by Michaelsen (1900: 98) and Ude (1929:66) differ clearly from the North and South American specimens of $F$. agricola by the shape of the peptonephridia, the place of origin of the dorsal blood vessel and the origin of the excretory ducts on the post-septal portions of the nephridia. However, the material identified by Southern (1907: 75) and Nielsen \& Christensen (1959:82) as $F$ perrieri resembles in some characters the South American and Moore's specimens of $F$. agricola. As my material is well characterized by Moore's and Bittencourt's descriptions, I prefer to maintain the name $F$. agricola Moore, 1895 . It is possible, notwithstanding, that $F$. agricola is only a synonym of $F$ perrieri. 
Geographical distribution - USA: Philadelphia (Moore, 1895: 343); England: Cockermouth (Michaelsen, 1900: 97); Sweden: Bohuslän (Backlund, 1947: 13); Brazil: São Paulo (Christoffersen, 1973: 340; Bittencourt, 1974: 374) and São Vicente (new locality).

\section{Fridericia bollonsi Benham, 1914}

Fridericia bollonsi Benham, 1914: 175, figs. 1-6; Christoffersen, 1976: 244, figs. $16-25$.

Material - Engenheiro Ferraz, in a dry watercourse close to the railroad tracks, 2 animals (ZU-367), M.L. Christoffersen col. 21.12.1975.

Discussion - The animals resemble closely the material formely described from São Paulo (Christoffersen, 1976:244). They differ slightly by having the dorsal lobes of the third pair of septal glands independent of each other, those of the second pair connected by a narrow and little developed glandular mass and those of the first pair connected by a thicker glandular mass occupying in length the posterior third of the respective dorsal lobes. They differ also by not containing a developed mass of sperm cells filling the cavities of segments $X$ and XI. Each peptonephridium has 2-3 elongate terminal branches in segment $\mathrm{V}$. The chloragogen cells are well developed from segment $\mathrm{V}$ backward, having conspicuous cellular contours. There are five pairs of preclitellar nephridia, located on septa $6 / 7$ to $10 / 11$.

Geographical distribution - Kermadec Islands (Benham, 1914: 174); Brazil: São Paulo, Pirassununga, Birigui (Christoffersen, 1976: 244) and São Vicente (new locality).

\section{ACKNOWLEDGEMENTS}

I thank Dr. Gilberto Righi for supervising this work, which was carried out with the aid of a scholarship from the "Fundação de Amparo à Pesquisa do Estado de São Paulo"

\section{LITERATURE CITED}

BACKLUND, H.O. 1947 - Swedish Enchytraeidae. II. Acta Univ. lund., N.F. Avd. 2, 43 (8): 1-32, pls. 1-2

BELL, A.W. 1936 Three new species of Fridericia (Enchytraeidae) from Califonia. Univ. Calif. publ. zool., 41 (12): 145-164.

BENHAM, W.B. 1914 - Oligochaeta from the Kermadec Islands. Trans. Proc. N.Z. Inst., 47: 174185.

BITTENCOURT, E.C.R. 1974 Algumas Enchytraeidae (Oligochaeta) de São Paulo. Rev. hras. Biol., 34 (3): 369-378.

CERNOSVITOV, L. 1930 Eine neue Enchytraeiden-Art aus Ameisenhaufer Argentiniens. Zool. Anz., 88: 85-89. 
CERNOSVITOV, L. 1934 - Zur Kenntnis der Enchy traeiden. II. Ibid., 105: 295-305.

CERNOSVITOV, L. 1937 Notes sur les Oligochaeta (Naididées et Enchyrtraeidées) de l'Argentine. An. Mus. argent. Cienc. nat., 39: 135-157.

CERNOSVITOV, L. 1939 The Percy Sladen Trust expedition to Lake Titicaca. VI. Oligochaeta. Trans. Linn. Soc. Lond., (3) 1 (1): 81-116.

CHRISTOFFERSEN, M.L. 1973 - Sistema excretor de Fridericia agricola Moore, 1895 (Oligochaeta, Enchytraeidae). Ciênc. Cult., S. Paulo, Suppl., 25 (6): 340.

CHRISTOFFERSEN, M.L. 1976 - Two species of Fridericia Mich., 1889 (Oligochaeta, Enchy traeidae) from Brazil. Bolm Zool., Univ. S. Paulo, 1: 239-256.

CHRISTOFFERSEN, M.L. 1977 - New Species of Guaranidrilus Cernosv. (Enchy traeidae, Oligochaeta) from Serra do Mar, São Paulo, Brazil. Stud. neotr. Faune Env., 12: 187-206.

COGNETTI DE MARTIIS, L. 1927 Lumbricidi dei Carpazi. Boll. Musei Lab. Zool. Anat. comp. R. Univ. Genova, (2) 7 (10): 1-8.

FRIEND, H. 1912 - British Enchytraeids III. Journ. Roy. microsc. Soc., p. 9-27 (not seen).

MICHAELSEN, W. 1900 Oligochaeta. Das Tierreich, 10, 575 p., R. Friedlander \& Sohn, Berlin.

MOORE, J.P. 1895 Notes on American Enchytraeidae. I. New species of Fridericia from the vicinity of Philadelphia. Proc. Acad. nat. Sci. Philad., p. 341-345.

NIELSEN, C.O. \& B. CHRISTENSEN 1959 The Enchytraeidae. Critical revision and taxonomy of European species (Studies on the Enchytraeidae VII). Natura jutl., 8/9: 1-160.

NURMINEN, M. 1966 Further notes on the Enchytraeids (Oligochaeta) of Spitsbergen. Ann. Zool. Fenn., 3: 68-69.

NURMINEN, M. 1967a Ecology of enchytraeids (Oligochaeta) in Finnish coniferous forest soil. Ibid., 4: 147-157.

NURMINEN, M. 1967b Faunistic notes on North-European enchytraeids (Oligochaeta). Ibid., 4: $567-587$.

NURMINEN, M. 1970 Records of Enchytraeidae (Oligocheta) from the west coast of Greenland. Ibid., 7: 199-209.

NURMINEN, M. 1973a Enchytraeidae (Oligocheta) from the vicinity of Montreal, Canada. Ibid., 10: $399-402$.

NURMINEN, M. 1973b - Enchytraeidae (Oligochaeta) of Iceland. Ibid., 10: 412413.

NURMINEN, M. 1973c Enchytraeidae (Oligochaeta) from the vicinity of Lake Baikal, Siberia. Ibid., 10: 478-482.

RIGHI, G. 1974 Notas sobre os Oligochaeta, Enchytraeidae do Brasil. Papéis avulsos zool. S. Paulo, 28 (7): $127-145$.

ROSA, D. 1887 Il Neoenchytraeus bulbosus n.sp. Boll. Musei Zool. Anat. comp. R. Univ. Torino. 2 (29): 1-3.

SOUTHERN, R. 1907 - Oligochaeta of Lambay. Ir. Nat., 16: 62-82, pls. 18-19.

STEPHENSON, J. 1924 Oligochaeta of the Siju Cave, Garo Hills, Assam. Rec. Indian Mus., 26 (1): 127-135, pl. 6 . 
STEPHENSON, J. 1931 - Descriptions of Indian Oligochaeta. II. Ibid., 33 (2): 173-202.

UDE, H. 1929 Oligochaeta. In: F. Dahl, Die Tierwelt Deutschlands, 15, 132 p., Gustav Fisher, Jena.

WELCH, P. S. 1914 Studies on the Enchytraeidae of North America. Bull. Ill. State Lab. nat. Hist., 10: 123-211.

\section{ABBREVIATIONS UTILIZED IN FIGURES}

a, ampulla of spermatheca.

cc, cutaneous cells.

$\mathrm{cg}$, cerebral ganglion.

ch, cloragogen cell.

cl, clitellar cell.

cp, cephalic pore.

cut, cuticle.

dl, dorsal lobe of septal gland.

dv, dorsal blood vessel.

ep, ectal pore of spermatheca.

$i$, intestine.

Im, longitudinal musculature.

1s, lateral setae.

$\mathrm{m}$, muscular coating. nc, ventral nerve cord.

$\mathrm{pb}$, penial bulb.

pbi, penial bulb invagination.

pep, peptonephridium.

ph, pharynx.

pp, penial pore.

$\mathrm{ppb}$, post-pharyngeal bulb.

$r$, posterior recess in pharynx.

$\mathrm{rm}$, retractor muscle.

sd, seminal duct.

sg, secondary glandular thickening of septal gland.

sp, sperm cells.

vl, ventral lobe of septal gland. 